\title{
Robert Szymula
}

Uniwersytet w Białymstoku

\section{МЕСТО ЗАИМСТВОВАННОЙ ЛЕКСИКИ В СОВРЕМЕННОМ РУССКОМ ПОЛИТИЧЕСКОМ ДИСКУРСЕ}

\author{
SUMMARY \\ English loanwords in modern Russian political discourse
}

The paper focuses on the analysis of English loanwords in modern Russian political discourse. The author presents ways of borrowing lexical units from English into Russian and shows semantic modifications that take place during the process. Three basic lexical groups are distinguished in the analyzed data: loanwords that had negative connotations in the Soviet times but have lost them and become neutral words in modern times; loanwords that had neutral connotations in the Soviet times; loanwords with negative connotations in both the Soviet and modern times (loanwords conveying negative judgments).

Key words: terminology, political discourse, loanwords.

\section{STRESZCZENIE}

\section{Zapożyczenia z języka angielskiego we współczesnym rosyjskim dyskursie politycznym}

Obiektem analizyw niniejszymartykulesązapożyczeniazjęzyka angielskiegowewspółczesnym dyskursie politycznym. Autor przedstawia sposoby wchodzenia danych zapożyczeń w język rosyjski oraz zmiany semantyczne, które $\mathrm{w}$ tym procesie zachodziły. W badanym materiale wyodrębniono 3 grupy leksyki: zapożyczenia, które w czasach sowieckich miały konotacje negatywne, a w czasach współczesnych utraciły ją i stały się neutralne; zapożyczenia, które w czasach sowieckich miały neutralne konotacje; zapożyczenia, które w czasach sowieckich i współcześnie mają negatywne konotacje (słowa, oznaczające zjawiska negatywne). 
Политические изменения в России повлекли за собой изменения в политическом и общественном сознании, отражающиеся в системе языка в целом, а в частности в языковых средствах, используемых в политическом дискурсе. В связи с этим представляется интресным проследить эти изменения в лексико-семантическом аспекте.

Понятие «дискурс» (фр. discours - речь, выступление) разработано Мишелем Фуко еще в 60-е годы. А. Миллер дает следующее определение этого понятия: «Дискурс - отложившийся и закрепленный в языке способ упорядочения действительности и видения мира. Выражается в разнообразных (не только вербальных) практиках, а следовательно, не только отражает мир, но проектирует и сотворяет его» ${ }^{2}$ А. Н. Баранов и Е. Г. Казакевич определяют политический дискурс следующим образом: «Совокупность речевых актов, используемых в политических дискуссиях, а также правил публичной политики, освещенных традицией и проверенных опытом, образует политический дискурс»².

В политический дискурс входят газетно-публицистические тексты, ораторские выступления, которые посвящены политике, официальные тексты на политическую тему, например, постановления, указы, законы, и, наконец, научные политологические статьи, т. е. статьи, в которых политика изучается с научной точки зрения. Каждая из этих разновидностей политического дискурса выполняет свои задачи, например, задача официальных постановлений, указов, законов - создать юридическую базу для политической деятельности, задача газетно-публицистических статей, ораторских выступлений - воздействовать на адресата речи, задача научных политологических работ - изучать политическую жизнь с объективной точки зрения.

А. Н. Баранов и Е. Г. Казакевич отмечают, что политический язык - это осообая знаковая система, предназначенная именно для политической коммуникации, для выработки общественного консенсуса, принятия и обоснования политических и социально-политических решений в условиях множественных общественных интересов истинно плюралистического общества, в котором каждый человек является не объектом идеологическо-

1 А. Миллер, О дискурсивной природе национализмов, «Pro et Contra» 1997, Т. 2, № 4, s. $141-151$.

2 А. Н. Баранов, Е. Г. Казакевич, Парламентские дебаты: традиции и новации. Советский политчческий язык (от ритуала к метафоре), Москва 1991, s. 61. 
го воздействия и манипулирования, а субъектом политического действия ${ }^{3}$. Тем самым ситуация, существовавшая в советские времена противопоставляется нынешнему положению дел.

На негибкость и формульность советского политического дискурса указывает Е. В. Какорина. По ее наблюдениям советский политический дискурс (особенно в период с середины 60-х до середины 80-х гг) представлял собой неестественно стабильную систему. Круг тем был заранее задан, оценки были социально санкционированы, существовала устоявшаяся система фразеологических средств, использовались отобранные в ходе становления традиции образы-клише.

А. Н. Баранов и Е. Г. Казакевич указывают на ритуализацию политического языка в советские времена. На их взгляд, ритуализация языка является непеременным условием функционирования политической культуры, основанной на том, что супер-эго «народ» занимает в политическом дискурсе одновременно 2 места - субъекта («от имени которого все делается») и адресата («во имя которого все делается») ${ }^{5}$. По мнению этих исследователей, в доперестроечные времена политический язык не выполнял функцию средства коммуникации, следовательно, политического дискурса как такового не было. Ученые объясняют этот факт так: «(...) в политическом дискурсе «народ» как супер-эго был представлен в виде отдельных неавтономных псевдополитических субъектов, которые не нуждались в реальном диалоге, но имитировали его, поневоле ритуализируя политическую коммуникацию 6 . Подлинный политический дискурс стал возможным лишь в наше время.

Известно, что лексика - самый динамичный ярус языка, который быстрее и более наглядно чем другие ярусы языка реагирует на политические, социальные и экономические изменения общества. «Непосредственная обращенность лексики к внеязыковой действительности - замечает Д. Н. Шмелев - является ее существенной особенностью по сравнению со всеми другими областями языка, и вряд ли всестороннее исследование лексики осуществимо без учета этой особенности» ${ }^{7}$. Связь лесксики

3 А. Н. Баранов, Е. Г. Казакевич, Парламентские дебаты: традиции и новации. Советский политический язык (от ритуала к метафоре), Москва 1991, s. 6.

4 Е. В. Какорина, Стилистические изменения в языке газеты новейшего периода. Автореф. канд. дисс., Москва 1992, s. 18.

5 А. Н. Баранов, Е. Г. Казакевич, Парламентские дебать: традиции и новации. Советский политический язык (от ритуала к метафоре), Москва 1991, s. 14.

6 Там же, s. 15-16.

7 Д. Н. Шмелев, Проблемы семантического анализа лексики (на материале русского языка), Москва 1973, s. 15. 
с внеязыковой действительностью еще более очевидна, когда мы говорим о политическом дискурсе. Однако следует отметить, что причинами изменения языка политики являются не только экстралингвистические факторы, наряду с ними надо принимать во внимание и внутриязыковые факторы.

Одно из существенных изменений лексико-семантических единиц языка современной политики - это изменение коннотации. Лексика коммунистической идеологии в сегодняшнее время отсутствует или используется в отрицательном или ироническом смысле. Фактически эта лексика превращается в историзмы или лексику с негативной экспрессивной оценкой. Появление новых реалий и явлений требует названия. Для этого используется лексика, которая в советские времена употреблялась только для описания зарубежной действительности. Возвращаются многие слова, которые были вытеснены из употребления. Использование этих слов в новой коммуникативной ситуации сопровождается изменением коннотаций, которые были присущи словам в советские времена.

В данной статье мы сосредоточим внимание на особенностях употребления заимствований из английского языка в языке политики. Лингвисты в значительной степени расходятся в понимании термина «заимствование». До сих пор не удалось прийти к единой трактовке этого ключевого понятия и придать ему терминологическую точность. Л. П. Крысин определяет заимствование как «процесс перемещення различных элементов из одного языка в другой» ${ }^{8}$, подчеркивая всеобъемлющий характер заимствования, которое распространяется на элементы всех уровней языка. При этом подчеркивает, что единицы разных уровней языка обладают неодинаковой способностью к перемещению из одного языка в другой: лексические, семантические, синтаксические и стилистические элементы могут перемещаться самостоятельно, тогда как фонетические, фонологические, морфологические элементы перемещаются, находясь в составе иноязычных слов. С. А. Беляева считает, что заимствование - это «сложное преобразование иноязычного материала в новой среде» и представляет его как путь, который проходит иноязычное слово от чужого к своему․ Таким образом, заимствование, по мнению этой ученой, отождествляется с процессом освоения иноязычных слов. Широкий взглял на понятие заимствования отличает таких ученых, как Ж. Вандриес, который считал заимствованием вхождение в литературный

8 Л. П. Крысин, Социолтнгвистические аспекты изучения современного русского языка, Москва 1989, s. 56.

9 S. А. Беляева, Английские слова в русском языке XVI-XX вв., Владивосток 1984, s. 5. 
язык жаргонизмов и диалектизмов ${ }^{10}$, и С. Н. Карцевский, еще более расширяющий понятие заимствования за счет включения в него явления перехода в общеупотребительную лексику специальных слов (помимо жаргонных и диалектных $)^{11}$. Также А. А. Реформатский замечает: «Могут быть заимствования и внутри одного языка, когда общий литературный язык заимствует что-либо из диалектов, профессиональной речи, жаргонов и наоборот» ${ }^{12}$.

В современном языкознании основной причиной заимствования слов принято считать причины нелингвистического характера. Собранный нами материал показывает, что основными причинами проникновения иностранных слов в язык политики являются именно экстралингвистические причины.

На современном этапе русский политический язык наполнился за сравнительно короткий промежуток времени большим числом новых иностранных слов, прежде всего англицизмов. Это обусловлено новыми социально-экономическими условиями жизни, контактами России с другими странами. В связи с отменой цензуры и ориентацией общества на свободу самовыражения происходит также процесс обновления устойчивого политического лексикона за счет внутренних языковых ресурсов. По сравнению с советской эпохой, сейчас сняты жанровые и идеологические ограничення, и уже ничто не препятствует проникновению иноязычной лексики в политический язык. Л. П. Крысин пишет по этому поводу: «Осознание своей страны как части всего цивилизованного мира, преобладание интегративных, объединительных тенденций над тенденциями, отражавшими противопоставление советского общества и советского образа жизни западным, буржуазным образцам, переоценка социальных ценностей и смещение акцентов с классовых и партийных приоритетов на общечеловеческие, наконец, открытая ориентация на Запад в области экономики, политической структуры государства (...) - все эти процессы и тенденции, характерные для русского общества второй половины 80-х - 90-х годов, несомненно, послужили важным стимулом, облегчившим активизацию употребления иноязычной лексики» ${ }^{13}$.

Этот процесс сопровождается интересными семантическими изменениями. Многие ранее заимствованные слова расширили свое значение, изменили свою оценочную окраску. Это особенно наглядно демонстрируют

10 Ж. Вандриес, Язык. Лингвистическое введение в историю, Москва 1937, s. 212.

11 S. Н. Карцевский, Язык, война и революиия, Берлин 1923, s. 17.

12 А. А. Реформатский, Ввдение в языкознание, Москва 1955, s. 117.

13 Л. П. Крысин, Иноязычное слово в контексте современной общественной жизни, [w:] Русский язык кониа ХХ столетия (1985-1995), Москва 1996, s. 143. 
те заимствованные слова, которые в советскую эпоху употреблялись для обозначения только зарубежных реалий. В русской лексикологии заимствованные слова такого типа назывались экзотизмами. Под экзотизмами понимаются такие иностранные слова, в семантике которых присутствует национально-культурный компонент, специальное указание на определенное локально-ограниченное распространение соответствующей реалии ${ }^{14}$. Национально-культурный компонент в скрытом виде присутствует в семантике большинства иноязычных слов в начальный период употребления в заимствующем языке, но отчетливое его выделение происходит только в определенных условиях - в текстах, описывающих жизнь в странах языкаисточника, обычаи и образ других народов.

Наши наблюдения показывают, что англо-американские экзотизмы довольно многочисленная группа англицизмов, регулярно используемых в русском языке политики. Социальная оценочность языка средств массовой информации предопределила их особую роль в языке советской эпохи, так как их употребление в это время обусловливалось идеологическим противостоянием ${ }^{15}$.

Возникновение и закрепление отрицательной оценки может быть связано с вопросами воздействия идеологии на функционирование языка. В языке публицистики выделяется подсистема идеологически связанной лексики, принадлежащей к системе понятий определенной идеологии, которая составляет активный словарь политики. Роль идеологически связанной лексики - служить средством формирования общественного мнения, поэтому семантика ключевых слов идеологии и политики включает прагматические семы, не совпадающие в разных общественных системах ${ }^{16}$.

Англо-американские экзотизмы оказались вовлеченными в сферу идеологически обусловленной лексики, но в отличие от идеологически связанных слов, они относились к периферийной зоне языка политики, играли роль дополнительных средств. От обычных экзотизмов слова подобного типа отличались отрицательной коннотацией, маркирующей иноязычное слово как идеологически чуждое.

Отрицательная коннотация англицизмов создавалась различными способами. Прежде всего, она возникала в результате переосмысления собственно экзотического семантического компонента в значении англицизмов, указывающего на распространение реалии, в компонент идеологи-

14 Е. М. Верещагин, В. Г. Костомаров, Язык и культура, Москва 1990, s. 42.

15 Г. Я. Солганик, Об особенностях языка газеты, «Русский язык за рубежом» 1988, № 5, s. 35.

16 Т. Б. Крючкова, К вопросу о многозначности «идеологически связанной» лексики, «Вопросы языкознания» 1982, № 1, s. 28-31. 
ческого плана, который маркирует слово как знак, описывающий другую действительность, социум с иным общественным порядком. Кроме того, семантика слов, непосредственно относящихся к сфере идеологии, не только приобретает отрицательные коннотации, но и претерпевает определенный семантический сдвиг.

Яркой негативной окраской в советском языке политики обладали англицизмы - наименования определенных политических кругов, обладающих влиянием, а также обозначения лиц, представителей этих кругов. Примером могут служить лексемы истеблишмент (истэблишмент) (англ. establishment) и лобби (англ. lobby). Эти слова обозначали реалии, присущие буржуазному обществу, и в связи с этим приобретали отрицательную коннотацию.

В современный период произошли значительные перемены в употреблении англо-американских экзотизмов в русском языке. Прежде всего, они изменили свою оценочную окраску, стали употребляться для обозначения также российских реалий.

Переход из экзотизмов с идеологической коннотацией в заимствованные слова происходил по-разному. Заимствование слова истеблишмент не связано с обозначением новой реалии. Понятие «правящие и привилегированные социальные группы» в русском языке обозначалось описательно при помощи словосочетаний «правящие верхи», «правящая верхушка». Англицизм истеблишмент, таким образом, стал применяться по отношению к явлению, не имеющему отдельного однословного названия в русском языке. Особенностью слова истеблишмент является освобождение от отрицательной эмоционально-экспрессивной окраски идеологического характера. Сравним: «правящие и привилегированные группы буржуазного общества, а также вся система власти и управления, с помощью которой они осуществляют свое господство» ${ }^{17}$, «совокупность государственных, экономических, социально-политических институтов, организаций, групп, обладающих власью и возможностью влияния на общественную жизнь; лица, занимающие основные позиции в этих органах и группах» ${ }^{18}$. В современном политическом дискурсе это слово употребляется с нейтральной оценкой. Приведем примеры:

1. А зря: из его рядов вышел весь нынешний российский истеблишмент, включая президента, премьер-министра и спикеров обеих палат ${ }^{19}$.

17 Словарь иностранных слов, Москва 1982, s. 203.

18 Толковый словарь русского языка кониа ХХ века. Языковые изменения, под ред. Г. Н. Скляревской, Санкт-Петербург 1998, s. 279.

19 «Аргументы и факты», № 44, 29.10.2008, http://www.aif.ru/society/article/22229/8 (dostęp: 10.09.2012). 
2. Поэтому Путину еще предстоит столкнуться с тем, что американские консерваторы называют "культурными войнами», войной не с самим истеблишментом, но с питающим истеблишмент консервативным этосом большинства ${ }^{20}$.

3. Но провожал официальный истеблишмент Химок бывиего мэра тем не менее красиво, со слезой, оказывается, у него в городе было много не только оппонентов, но и поклонников ${ }^{21}$.

Современное словоупотребление англицизма истеблишмент показывает также, что намечается тенденция к расширению, обобщению значения путем включения слова в словосочетания типа «художественный истеблишмент», «литературный истеблишмент» и т. п. В таком употреблении англицизм приобретает значение «влиятельные, авторитетные круги» (не только в политике, но и в других сферах жизни). Приведем примеры:

1. Несмотря на свою долгую принадлежность $\kappa$ советскому художественному истеблишменту (Гелий Михайлович удостоился когда-то целого ряда почетных званий и премий, а в 1968-1975 годы даже возглавлял Союз художников РСФСР), он всегда был довольно независимым твориом ${ }^{22}$.

2. Шоу непременно покажут по ТВ, присутствовать на празднике в «Крокусе» обещзал весь поп-музыкальный истеблишмент ${ }^{23}$.

3. Понял, что для титературного истеблишмента я все равно не существую, понял, что масс-маркет меня все равно будет знать no «Mетро» ${ }^{24}$.

4. На футбольном поле сразятся российские политики, бизнесмень, деятели культуры и искусства с представителями культурного истеблишмента Англии 25 .

Судьбу англицизма истеблишмент повторяет слово лобби. Лишившись отрицательной коннотации идеологического характера, эта лексема вместе с ней потеряла семантический компонент, определяющий соответствующее явление как отрицательное - «система контор и агентств крупных монополий при законодательных органах США, оказывающих в интересах этих мо-

20 «Известия», 6.03.2012, http://izvestia.ru/news/517657 (dostęp: 10.09.2012).

21 «Московский Комсомолец», № 26018, 18.08.2012, http://www.mk.ru/moscow/article/2012/08/ 17/738170-u-novogo-i-o-glavyi-himok-dva-mesyatsa-do-vyiborov-a-planov-gromade.html (dostęp: 10.09.2012).

22 «Известия», 28.03.2012, http://izvestia.ru/news/520084 (dostęp: 10.09.2012).

23 «Известия», 26.01.2012, http://izvestia.ru/news/513208 (dostęp: 10.09.2012).

24 «Московский Комсомолец», № 26033, 5.09.2012, http://www.mk.ru/culture/interview/2012/09/ 03/743698-kakoe-buduschee-zhdet-metro.html (dostęp: 10.09.2012).

25 «Известия», 1.06.2012, http://izvestia.ru/news/526103 (dostęp: 10.09.2012). 
нополий воздействие (вплоть до подкупа) на законодателей и государственных чиновников в пользу того или иного решения при принятии законов, размещении правительственных заказов и т. п.» ${ }^{26}$. Тенденция «улучшения» семантики этого слова отражена, например, в «Толковом словаре русского языка конца ХХ в. Языковые изменения», где его значение подается следующим образом: «представители тех или иных экономически сильных структур, влияющие на принятие законодателями или правительством решений в пользу таких структур» ${ }^{27}$.

Как показывают примеры, в прессе кроме слова лобби часто употребляются также производные от него лексемы лоббист, лоббирование, лоббировать, что можно объяснить большой степенью адаптации к русской лексической системе:

1. Их лобби обязано раскрыть инбормацию о своих доходах; о том, с кем из должностных лии, он обсуждал дела компании, интересы которой он представляет; списки экспертов, которые помогали ему убеждать общество и т. ${ }^{28}{ }^{28}$.

2. Он настаивает на необходимости в борьбе с табачным лобби ${ }^{29}$.

3. Уж очень сильно в Петербурге строительное лобби . $^{30}$.

4. Страховое лобби опротестовало закон из-за строгих ограничений своей деятельности ${ }^{31}$.

5. У банков очень мощное лобби, поэтому они считают, что могут вводить какие угодно новые комиссии, что неприемлемо, - отмечает председатель ОЗПП Михаил Аншаков ${ }^{32}$.

6. Однако, несмотря на большое число лоббистов этого законопроекта, хватает и отрииательно настроенных депутатов в самой Думе ${ }^{33}$.

7. Впрочем, назначение губернатором ранее в политике особо не засветившегося Сергея Ерощенко многие всерьез расиенили как результат лоббирования его кандидатуры главой «Ростехнологий» Сергеем Чемезовым и олигархом Михаилом Прохоровым ${ }^{34}$.

26 Словарь иностранных слов, Москва 1982, s. 282.

27 Толковый словарь русского языка конца ХХ века. Языковые изменения, под ред. Г. Н. Скляревской, Санкт-Петербург 1998, s. 362.

28 «Аргументы и факты», № 18, 5.05.1020, http://www.aif.ru/money/article/34503 (data dostępu 10.09.2012).

29 «Московский Комсомолец», 4.09.2012, http://www.mk.ru/social/article/2012/09/04/743877-onischenko-pozhalel-tri-milliona-alkogolikov.html (dostęp: 10.09.2012).

30 «Известия», 17.07.2012, http://izvestia.ru/news/530602 (dostęp: 10.09.2012).

31 «Известия», 28.06.2012, http://izvestia.ru/news/528899 (dostęp: 10.09.2012).

32 «Известия», 16.07.2012, http://izvestia.ru/news/530274 (dostęp: 10.09.2012).

33 «Известия», 22.08.2012, http://izvestia.ru/news/533414 (dostęp: 10.09.2012).

34 «Московский Комсомолец», 5.09.2012, http://baikal.mk.ru/article/2012/09/05/744718-100-dneybez-raskachki.html (dostęp: 10.09.2012). 
8. Никакой ревизии, никакого отката назад, сколько бы ни пьтались лоббировать такого рода решения отдельные предпринимательские структурь, не будет ${ }^{35}$.

Таким образом, очевидно, что слова истеблишмент, лобби, бывшие идеологические экзотизмы, при переходе из периферийной политической лексики в активный словарь приобрели нейтральную коннотацию.

Слово плюрализм в советском политическом языке употреблялось с ярко выраженной негативной идеологнческой коннотацией. В «Словаре русского языка» С. И. Ожегова оно толкуется как философский термин «идеалистическое философское направление, считающее, в противовес материалистическому монизму, что в основе мира и его явлений лежит несколько начал» ${ }^{36}$. В «Словаре иностранных слов» у него отмечены два значения: 1) философское идеалистическое учение, утверждающее (в противоп. монизму), будто в основе мира лежит множество самостоятельных, независимых духовных сущностей; 2) одна нз главных идей в современных буржуазных и реформистских теориях общественного устройства, состоящая в том, что общественно-политическая жизнь якобы представляет собой состязание, конкуренцию множества социальных групп и представляющие их интересы партий и иных организаций; п. противопоставляется марксистско-ленинскому учению о классах и классовой борьбе $\mathrm{e}^{37}$.

Такая тенденция наблюдается в употреблении многих иноязычных слов в политическом языке современного периода. В качестве иллюстрации рассмотрим несколько других лексем.

Как показывают наши наблюдения, в настоящее время значение этого заимствованного слова значительно расширяется, в основном употребляется в значении «множественность мнений, взглядов, направлений, партий и т. п. как один из принципов общественного устройства» ${ }^{38}$. В современном употреблении плюрализма идеологический компонент семантики «в буржуазных теориях», использовавшийся в языке доперестроечного периода для формирования «образа врага», полностью снят. Отрицательная идеологическая коннотация, которая раньше была присуща слову плюрализм, сменилась нейтральной. Приведем примеры:

1. Я в иелом пессимистично отношусь к государственной молодежной политике и полагаю, что в условиях политического плюрализма

35 «Аргументы и факты», № 20, 13.05.2009, http://www.aif.ru/money/article/26723 (dostęp: 10.09.2012).

36 S. И. Ожегов, Словарь русского языка, Москва 1970, s. 515.

37 Словарь иностранных слов, Москва 1982, s. 385.

38 Л. П. Крысин, Толковый словарь иностранных слов, Москва 2007, s. 602. 
государственное регулирование в этой сфере в приниипе невозможно, - заявил Дмитрий Гавра

2. Вот только в данном конкретном случае, как мне кажется, никакого плюрализма мнений быть не может, и всякий христианин, если он таковой в действительности, должен исходить из того, что сказал сам Христос: «Милости хочу, а не жертвы»» ${ }^{40}$.

3. Если мы говорим о плюрализме, демократии и свободе слова, естественно, для этого у нас должен быть независимый источник информирования общества, который будет рассказывать народу о реальном положении дел, а не так, как это делает сегодня Первый

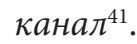

4. Политик уверен, что вместо того, чтобы развивать плюрализм мнений и конкуренцию, власть увеличивает разрыв междунаселением и государством, тем самым отталкивая граждан, которые готовы бъли участвовать в модернизаиии ${ }^{42}$.

Таким образом, изменив идеологическую оценочность, потеряв семантический компонент, определяющий его как отрицательное явление, слово плюрализм становилось одним из ключевых слов современной эпохи.

Регулярно употребляемым в языке политики является также англицизм имидж. Эта лексема давно проникла в русский язык, но стала очень популярной в середине 90-х годов ХХ века. О. С. Мжельская и Е. И. Степанова замечают, что в конце 70 -х годов слово имидж вошло в русский язык со значением «образ» и долго употреблялось как экзотизм. Его значение в это время имело семантические вариации: 1) Образ, создаваемый самим человеком, средствами массовой информации, общественное мнение об известном человеке (актере, политическом деятеле), надуманная роль, которую человек играет в жнзни; 2) Образ, принимаемый за массовый идеал ${ }^{43}$. В начале 80-х годов значение англицизма имидж носило оттенок отнесенности к капиталистическому миру, имело отрицательную окраску: «рекламный образ кого-либо (обычно политического деятеля), создаваемый средствами массовой информации (в капиталистических странах)» ${ }^{44}$. В начале же 90-х

39 «Известия», 21.08.2012, http://izvestia.ru/news/533423 (dostęp: 10.09.2012).

40 «Известия», 2.08.2012, http://izvestia.ru/news/532025 (dostęp: 10.09.2012).

41 «Московский Комсомолец», 30.05.2012, http://arh.mk.ru/article/2012/05/30/709572-deputatmaksim-korelskiy-obschestvennoe-ne-znachit-nezavisimoe.html (dostęp: 10.09.2012).

42 «Аргументы и факты», 05.06.2012, http://www.aif.ru/politics/news/137400/3 (dostęp: 10.09.2012).

43 О. S. Мжельская, Е. И. Степанова, Новейшие англииизмы в русском языке, [w:] Новые слова и словари новых слов, Ленинград 1983, s. 128-129.

44 Новое в ресской лексике. Словарные материаль - 80, Москва 1983, s. 81. 
годов англицизм имидж стал терять отрицательную коннотацию и употребляться с нейтральной окраской: «представление (часто целенаправленно создаваемое) о чьем-н. внутреннем и внешнем облике, образе» ${ }^{45}$.

В современный период значительно расширяется сочетаемость этого слова. Если раньше оно относилось только к людям, то теперь встречаются контексты, где это слово сочетается с неодушевленными существительными. Именно это значение зафиксировано в «Толковом словаре русского языка конца XX в.»: «впечатление, мнение о лице, коллективе, учреждении, вещи и т. п., создаваемое заинтересованными лицами; индивидуальный стиль, облик, характеризующий лицо, группу лиц, учреждение и т. п.» ${ }^{46}$. Приведем примеры:

1. Кроме того, добавила эксперт, надо радикально менять имидж чиновников ${ }^{47}$.

2. Политологи отмечают, что президент теряет не только рейтинг, но и имидж «героя» ${ }^{48}$.

3. Дерипаска нанес удар по имиджу президента РФ и России ${ }^{49}$.

4. Имидж страны имеет вполне прикладное, стоимостное значение: немало примеров, когда проекты с российским участием - даже такой знаковый проект, как «Северный поток», например тормозились только потому, что их настороженно воспринимала общественность тех или иных государств, - иитирует Медведева "Life News" 50 .

5. Разумеется, один инвестор этого не потянет, а вот у нескольких заинтересованных в имидже города, в том, чтобы их деньги не просто работали, а приносили Томску реальную пользу - это может получиться. И я надеюсь, что такие люди есть ${ }^{51}$.

6. «Гайдар Гайдаров сделал для партии много, содействуя в организации мероприятий и формировании проектов, способствуя укреплению положительного имиджа партии, - подчеркнули в пресс-службе. - За

45 Л. П. Крысин, Толковый словарь иностранных слов, Москва 2007, s. 295.

46 Толковый словарь русского языка конца ХХ века. Языковые изменения, под ред. Г. Н. Скляревской, Санкт-Петербург 1998, s. 264.

47 «Известия», 24.08.2012, http://izvestia.ru/news/533657 (dostęp: 10.09.2012).

48 «Московский Комсомолец», 11.09.2012, http://www.mk.ru/politics/article/2012/09/11/746872putin-perestal-byit-menshim-zlom.html (dostęp: 14.09.2012).

49 «Московский Комсомолец», 5.09.2012, http://eburg.mk.ru/article/2012/09/05/744552-alyuminievyiy-raskol.html (dostęp: 10.09.2012).

50 «Известия», 3.09.2012, http://izvestia.ru/news/534283 (dostęp: 10.09.2012).

51 «Московский Комсомолец», 12.09.2012, http://tomsk.mk.ru/article/2012/09/12/747536-ozeronadezhdyi.html (dostęp: 14.09.2012). 
избрание Гайдара Гайдарова секретарем проголосовали 96 делегатов конферениии» ${ }^{52}$.

Как показывают примеры, в прессе кроме слова имидж часто употребляется также производная от него лексема имиджмейкер:

1. В современной политике все образы сконструированы. Наличие спичрайтеров и имиджмейкеров, собственно, ни для кого не секрет $^{53}$.

2. Куда важнее было собрать средства на проведение кампании: на создание предвыборных итабов на местах, рекламу в прессе, оплату специалистов в самых разных областях, включая имиджмейкеров... ${ }^{54}$.

3. Избиратель стал более требовательным, стал глубже разбираться в ситуации. При этом, конечно, достаточно много тех, кто еще «покупается» на созданный имиджмейкерами образ политика и популистские высказывания ${ }^{55}$.

Хотя наши наблюдения показывают, что особенно большой группой среди англицизмов, наиболее актуально употребляемых в современном политическом языке, являются лексемы, которые изменили идеологическую коннотацию, среди заимствованных слов есть и такие, которые в советские времена не обладали отрицательной коннотацией, маркирующей их как идеологически чуждое. К таким словам относятся, например, англицизмы саммит, рейтинг и т. д.

В русском языке существует синоним англицизма саммит: «встреча на высшем уровне». Если раньше в информационных сообщениях использовался обычно русский оборот, то теперь употребление этого иноязычного слова актуализируется. Русский синоним не вытесняется из употребления, однако в газетно-публицистических текстах все же предпочтение отдается слову саммит. Приведем примеры:

1. «Мы готовы обсуждать с Японией любые вопросы, включая мирный договор, - заявил глава МИД РФ Сергей Лавров на саммите АТЭС во Владивостоке. - Главное - чтобы при этом соблюдалась законность, включая признание реалий, закрепленных в нормах $\mathrm{OOH} \gg^{56}$.

52 «Московский Комсомолец», 6.09.2012, http://baikal.mk.ru/news/2012/09/06/745306-glavoyirkutskogo-gorodskogo-otdeleniya-er-izbran-eksministr-zdravoohraneniya.html (dostęp: 10.09.2012).

53 «Известия», 20.02.2009, http://izvestia.ru/news/345786 (data dostępu 10.09.2012).

54 «Аргументы и факты», 23.04.2012, http://www.aif.ru/sport/article/51547/4 (dostęp: 10.09.2012).

55 «Московский Комсомолец», 23.05.2012, http://yaroslavl.mk.ru/interview/2012/05/23/706825glavnoe-dlya-nas-rabotat-v-interesah-zhiteley.html (dostęp: 10.09.2012).

56 «Известия», 5.09.2012, http://izvestia.ru/news/534499 (dostęp: 10.09.2012). 
2. Насаммит стран Азиатско-Тихоокеанского регионаво Владивостоке потратили около 600 млрд рублей 57.

3. Однако, какзаявил на саммите Владимир Путин, не стоит смотреть на этот процесс сложа руки, а нужно принимать соответствующие стимулируюшие мерь ${ }^{58}$.

Слово рейтинг впервые проникло в русский язык в составе шахматного термина "рейтинг-лист». Эта лексема характеризовалась как англицизм, который пришел в русский язык из спортивного языка, главным образом шахматного, в значении «личный рейтинг», т. е. индивидуальный числовой коэффициент оценки чьей-либо деятельности, меняющийся в зависимости от успехов его обладателя. В 90-е годы в связи с появлением конкуренции во всех областях, которая возникла в результате изменений в общественно -политической жизни России, этот англицизм стал активно употребляться в значении «цифровой показатель оценки чьей-л. деятельности, популярности кого-, чего-л. по отношению к другим, основанный обычно на результатах общественных опросов или на мнении экспертов» ${ }^{59}$. На его полное освоение оказало влияние отсутствие соответствия этому слову в русском языке. Приведем примеры:

1. Геннадию Тимченко на посту президента и председателя совета директоров ХК СКА удалось за одни только год радикально изменить профессиональное тицо клуба, обеспечить ему высокие спортивные рейтинги и превратить его в одного из ярких лидеров хоккейного марафона в рамках регулярного чемпионата КХЛ ${ }^{60}$.

2. Журнал,Fоrbes” составилрейтингдоходовроссийскихзнаменитостей. Место в рейтинге, согласно данным исследования, обеспечивают три фактора: доходы за год, внимание СМИ и интерес, который звезда вызывает у аудитории в интернете ${ }^{61}$.

3. Московский государственный университет имени Ломоносова занял 116-е место в ежегодно составляемом рейтинге лучших университетов мира ${ }^{62}$.

57 «Аргументы и факты», № 36, 7.09.2012, http://www.aif.ru/money/dontknow/10185 (dostęp: 10.09.2012).

58 «Московский Комсомолец», 12.09.2012, http://vlad.mk.ru/article/2012/09/12/747464-otkryitosti-kurs-na-innovatsii.html (dostęp: 14.09.2012).

59 Толковый словарь русского языка кониа ХХ века. Языковые изменения, под ред. Г. Н. Скляревской, Санкт-Петербург 1998, s. 542.

60 «Известия», 5.09.2012, http://izvestia.ru/news/534537 (dostęp: 10.09.2012).

61 «Аргументы и факты», 30.07.2012, http://www.aif.ru/culture/news/170933 (dostęp: 10.09.2012).

62 «Московский Комсомолец», 11.09.2012, http://www.mk.ru/social/news/2012/09/11/746850mgu-ne-voshel-v-sotnyu-luchshih-vuzov-mira.html (dostęp: 14.09.2012). 
В настоящее время употребление этого англицизма актуализируется в политическом языке. Семантика слова рейтинг оказалась подходящей, чтобы определить свои симпатии (антипатии) к тому или иному соревнующемуся политику, партии, группе и т. д. Приведем примеры:

1. При нынешнем равенстве рейтингов основных кандидатов исход выборов в значительной степени будет зависеть от итогов теледебатов ${ }^{63}$.

2. Впрочем, несмотря на существенное снижение рейтинга «Единой России», серьёзных попьток биться за избирателя, уходяшего от партии власти, ни коммунисты, ни ЛДПР не предпринимают и борются скорее между собой ${ }^{64}$.

3. В начале октября список из 39 кандидатов, набравших наибольший рейтинг, и мнение действующих членов совета будут представлень на рассмотрение президенту РФ Владимиру Путину ${ }^{65}$.

Среди иноязычных слов, вошедших в язык политики, можно выделить также группу лексики, которая обозначает негативные явления в обществе. Заимствование этой лексики обусловлено появлением или признанием многих явлений в современном российском обществе. Примером могут служить лексемы, такие как коррупиия или рэкет. Эти слова не изменили свою негативную коннотацию, так как сами явления, обозначающиеся ими, негативные. В процессе заимствования они потеряли лишь указание на локальное ограничение их употребления. Сравним: «Коррупция в буржуазных странах: подкуп взятками, продажность должностных лиц, политических деятелей» ${ }^{66}$, «Коррупция - подкуп взятками, продажность должностных лиц, политических деятелей» ${ }^{67}$, «Рэкет - в США - шантаж, вымогательство, запугивание, применяемые бандами гангстеров» ${ }^{68}$, «Рэкет - преступное вымогательство чужих доходов путем угроз и насилия» ${ }^{69}$. В настоящее время эти слова очень часто встречаются при описании российской общественно-политической ситуации. Приведем примеры:

63 «Известия», 4.09.2012, http://izvestia.ru/news/534367 (dostęp: 10.09.2012).

64 «Аргументы и факты», № 47, 23.112011, http://www.aif.ru/society/article/47538 (dostęp: 10.09.2012).

65 «Московский Комсомолец», 11.09.2012, http://www.mk.ru/politics/news/2012/09/11/746989sredi-kandidatov-v-chlenyi-spch-lidiruyut-hakamada-parfenov-i-kucherena.html (dostęp: 14.09. 2012).

66 S. И. Ожегов, Словарь русского языка, Москва 1970, s. 290.

67 Л. П. Крысин, Толковый словарь иностранных слов, Москва 2007, s. 401.

68 S. И. Ожегов, Словарь русского языка, Москва 1970, s. 440.

69 Л. П. Крысин, Толковый словарь иностранных слов, Москва 2007, s. 687. 
1. «Более того, он (Дерипаска) уже объяснил английскому суду, что он был объектом рэкета со стороны „Михаила Черного и Антона Малевского"», - отметил представитель владельиа «Базэла» ${ }^{70}$.

2. Ирина Зироян являлась вдовой и наследницей бизнеса Геворга Зирояна, который в 1990-е годы занимался рэкетом на юге Москвы ${ }^{71}$.

3. Он обратился к нам в полицию за помощью, заявил, что подвергается рэкету со стороны ОПГ

4. Главное управление экономической безопасности и противодействия коррупции МВД России направило в Следственный комитет результаты проверки, свидетельствующие о том, что действующий губернатор Брянской области Николай Денин «преследуя личную заинтересованность» причинил значительный ущерб бюджету региона ${ }^{73}$.

5. Сможет ли Россия победить коррупиию или коррупиия в коние кониов победит её? ${ }^{74}$.

6. Кроме этого, в дектарации сделан особый упор на борьбу с коррупичией $\breve{u}^{75}$.

Происходящие в обществе изменения обусловили активизацию употребления заимствованной лексики в современном русском политическом дискурсе. Заимствование иноязычных слов в современном русском политическом дискурсе связано с потребностью общества подчеркнуть связь с западной общественно-политической действительностью. Заимствования составляют, в основном, англицизмы. В условиях илеологического противостояния заимствования из английского языка выполняли роль идеологически маркированной лексики, используемой для формирования «образа врага» в прессе доперестроечного периода. Данные лексемы приобрели устойчивую отрицательную коннотацию.

Новые реалии и явления в обшественно-политической жизни современной России, а также отсутствие однословного названия существующих понятий способствовали актуализации употребления англицизмов, обозначавших соответствующие реалии и понятия зарубежной действительности.

70 «Известия», 31.10.2011, http://izvestia.ru/news/505472 (dostęp: 10.09.2012).

71 «Аргументы и факты», 2.03.2012, http://www.aif.ru/sport/news/116546 (dostęp: 10.09.2012).

72 «Московский Комсомолец», 22.08.2012, http://www.mk.ru/politics/article/2012/08/21/739008konflikt-glubokoy-zamorozki2.html (dostęp: 10.09.2012).

73 «Известия», 3.09.2012, http://izvestia.ru/news/534356 (dostęp: 10.09.2012).

74 «Аргументы и факты», № 5, 2.02.2011, http://www.aif.ru/society/article/40560 (dostęp: 10.09.2012).

75 «Московский Комсомолец», 12.09.2012, http://vlad.mk.ru/article/2012/09/12/747464-otkryitosti-kurs-na-innovatsii.html (dostęp: 14.09.2012). 
При процессе переориентации на российскую действительность, англицизмы потеряли семантический компонент, способствовавший возникновению отрицательной коннотации идеологического характера, и из отрицательно-оценочной перешли в нейтрально-оценочные. В свою очередь, слова, обозначавшие на Западе негативные явления, потеряли указание на их локально-ограниченное применение, но не изменили отрицательную коннотацию, так как сами явления, обозначаемые ими, - негативные. Следует подчеркнуть, что среди заимствованных слов есть и такие, которые в советские времена не обладали отрицательной коннотацией, маркирующей их как идеологически чуждое.

По мере актуализации употребления, у некоторых англицизмов наблюдается тенденция к расширению первоначальной семантики, что и позволяет им стать частью русской лексической системы. 